\title{
Oral Solution in Sachet
}

National Cancer Institute

\section{Source}

National Cancer Institute. Oral Solution in Sachet. NCI Thesaurus. Code C149720.

Medicinal product consisting of an oral solution presented in a sachet. 